УДК $81 ' 282.4$

DOI: $10.17223 / 19986645 / 53 / 6$

\title{
С.С. Скорвид
}

\section{О ПАРАЛЛЕЛЬНЫХ ПРОЦЕССАХ В СИНТАКСИСЕ ЗАПАДНОСЛАВЯНСКИХ ОСТРОВНЫХ ГОВОРОВ В СИБИРИ}

\begin{abstract}
Впервые предпринимается сквозное сопоставительное исследование схожих синтаксических явлений в чешском и польских переселенческих говорах, сохраняюшихся в Сибири. Устанавливается, что они представляют собой результат сложной интерференции систем исходных диалектов и русского языка, с которым эти говоры находятся в постоянном контакте. Прослеживаются общие направления воздействия на них общерусской системы и региональных диалектных разновидностей языка окружения, представленных в Сибири.

Ключевые слова: чешские диалекты, польские диалекты, островные переселенческие говоры, Западная и Восточная Сибирь, языковой контакт, глагольные и именные синтаксические конструкиии, деагентивность.
\end{abstract}

\section{Предмет описания и постановка проблем}

В наши дни закономерно возрастает интерес отечественных и зарубежных исследователей к изучению исчезающих островных говоров представителей западнославянских этносов (польского, чешского) в Российской Федерации. По большей части эти переселенческие идиомы локализуются в Сибири, где их появление было обусловлено миграцией соответствующих групп крестьян с территории европейской части Российской империи в конце XIX - начале XX в.

Наиболее обстоятельно исследованы польские говоры Сибири, один из которых - периферийный, северо-восточный «кресовый»- представлен в настоящее время уже только идиолектом единственной польскоговорящей жительницы села Белосток Кривошеинского р-на Томской области Марии Маркиш 1928 г. р. (см. о нем в статьях Н.Е. Ананьевой [1. С. 96-97] и [2. С. 467-468, 470-471]). Большее число носителей насчитывают другие два сохранившихся до наших дней идиома, это: 1) западносибирский польский, или мазурский, говор (далее ЗСП) в д. Александровка Краснотуранского р-на Красноярского края и д. Знаменка Боградского р-на Республики Хакасия (около 60 говорящих в возрасте от 45 до 80 лет - по преимуществу потомки колонистов с Волыни, переселившихся туда ранее из Восточной Пруссии) и 2) восточносибирский польский говор (далее ВСП) в д. Вершина Боханского р-на Усть-Ордынского Бурятского округа Иркутской обл. (около 200 говорящих в основном среднего и старшего возраста, являющихся потомками переселенцев из района Домбровского угольного бассейна на границе Малопольши и Силезии, который до 1918 г. находился в составе России). 
Названные говоры описаны в двух защищенных в Польше диссертациях: оставшейся в рукописи работе Е.В. Ступинского [3] и вышедшем в виде монографии исследовании С.Б. Митренги-Улитиной $[4]^{1}$, а также с разных сторон освещались в ряде других публикаций польских и российских лингвистов (из недавних назову работы Д. Пасько [5], А. Урминьской [6], М. Глушковского [7], Н.Е. Ананьевой [8, 9], И.М. Егорова [10, 11] и свою [12]).

Несколько менее подробно изучен западносибирский, или среднеприиртышский, чешский говор (далее ЗСЧ) в дд. Репинка, Новоградка и Воскресенка Репинского сельского поселения Калачинского р-на Омской обл. (около 25 активных носителей в возрасте от 60 до 80 лет, являющихся потомками переселенцев из колонии Чехоград в бывшей Таврической губернии - ныне Новгородкивка Мелитопольского р-на Запорожской обл. Украины). Этот идиом северо-восточночешского происхождения, обнаруживающий естественные генетические связи с чешскими переселенческими говорами на Украине и отчасти на Черноморском побережье Северного Кавказа в России (последние далее обозначаются как СКЧ), охарактеризован в нескольких моих публикациях (в частности, [13-15]) и в магистерской работе выпускницы Карлова университета в Праге Б. Гакеновой [16]. В аспекте межъязыковой интерференции в русской речи носителей ЗСЧ на некоторые признаки этого идиома указала М.А. Харламова [17].

Вплоть до последнего времени почти во всех работах перечисленные переселенческие идиомы либо анализировались по отдельности, либо при сопоставительном описании - группировались по принадлежности к диалектам того или иного языка (польские говоры Западной и Восточной Сибири, чешские говоры Западной Сибири и Северного Кавказа). Автор этих строк исходит из убеждения, что, несмотря на генетически обусловленную специфику каждого из названных говоров, безусловно требующую их самостоятельного рассмотрения, может быть создана также сравнительная типология их развития в ситуации, характеризующейся непрерывным контактом с господствующим языком окружения. Опыт построения

${ }^{1}$ В нижеследующем тексте, используя приводимые этими и другими авторами (Н.Е. Ананьева, К. Нич, С. Урбаньчик) польские диалектные примеры, я даю их в унифицированной транскрипции, которая применяется также для записи образцов польских и чешских говоров в РФ, собранных в разные годы мною и коллегами и хранящихся в аудиоархиве кафедры славистики и центральноевропейских исследований РГГУ. Палатализованные согласные я последовательно обозначаю апострофом, в польских (особенно мазурских) примерах - кроме альвеопалатальных шипящих [с́́] (аналогичного рус. [ч]), [క́s], [śs] и [źz], обозначаемых так в отличие от палатальных [ćc, [ś], [ś], [ź]; позиционное смягчение согласных перед [i], [e] не отмечается. Средненебный скользящий передается как j, а губно-губной - как u् (и лишь в интервокальной позиции как w); буквой $\mathbf{l}$ обозначается зубной боковой сонорный, совпадающий с русским [л]; глухой фрикативный велярный передается греческой буквой $\chi$, а его звонкий вариант буквой $\gamma ;$ не отмечается особым знаком оглушение [ř $]$ после [p], [t], [k]. Ударение обозначается знаком ' перед ударным гласным, в польских и чешских диалектных примеpax - только в русизмах и других словах, где его место отличается от регулярного (на предпоследнем слоге в польском языке, на первом - в чешском). 
такой типологии был предложен мною применительно пока только к фонетико-фонологическому и морфологическому уровням [18].

Проведенный анализ позволил заключить, что на этих двух уровнях все изучаемые идиомы демонстрируют в целом хорошую сохранность первоначальных диалектных систем; хотя и здесь они испытывали и испытывают влияние прежде всего русского языка окружения в его региональных разновидностях (далее РЯО). То или иное воздействие оказывают, в частности, русский тип ударения с редукцией безударных гласных, которая через русизмы распространяется и на сохраняющие место ударения исконные лексемы; русская система мягких согласных и их сочетаемость с последующими гласными; русский тип выражения/невыражения категории одушевленности существительных во множественном числе и образования форм прошедшего времени и сослагательного наклонения глагола; русское видоупотребление и выражение разных способов глагольного действия, включая закрепление региональных диалектных типов, таких как глаголы дистрибутивного СГД с префиксом ро- и бипрефиксальные с ропа- и роро-. Между тем уровню синтаксиса в данных говорах как при сопоставительном, так и при монографическом их описании до сих пор уделялось незаслуженно меньшее внимание.

Достаточно подробный раздел «Синтаксис» содержит только монография С.Б. Митренги-Улитиной о ВСП [4. С. 114-127]. В нем автор, с одной стороны, иллюстрирует на своем материале синтаксические явления, присущие устному разговорно-бытовому стилю речи, в рамках которого реализуется ВСП (неполные и эллиптические предложения, повторы и др.), а с другой - выборочно характеризует особенности строения словосочетаний в составе простого предложения и разных типов сложного предложения, представляющие собой либо малопольское диалектное наследие в обсуждаемом идиоме, либо результаты его взаимодействия с РЯО. Среди последних, фиксируемых главным образом в простом предложении, рассматриваются прежде всего так называемые «нарушения» глагольного управления под влиянием РЯО. Этот термин, возможно, приемлем применительно к случаям типа unucyli nos polsk'imu jizzykov'i ‘учили нас польскому языку' (дат. п., в общепольском стандарте - род. п. ${ }^{2}$ ), однако неточен по

\footnotetext{
2 Здесь следует заметить, что как в фонетике и морфологии анализируемых говоров, так и на уровне синтаксиса подкреплять указание на те или иные «нарушения» либо отклонения в них, обусловленные их контактом с РЯО, сравнением с состоянием, наблюдаемым в соответствующем современном стандартном (литературном) славянском языке, в принципе не вполне корректно. Разумеется, во всех случаях предпочтительнее привлечение диалектного материала, но и там, где современные литературные соответствия представляются исследователю достаточными в качестве tertium comparationis, он всякий раз - вольно или невольно - рассматривает их в более широком контексте, руководствуясь при этом соображениями вероятностного характера. Так, для вывода об изменении управления глагола исус́ в ВСП под влиянием РЯО доказательную силу имеет не столько констатация отличного управления соответствующего глагола в общепольском стандарте, сколько полное совпадение сочетаемости и семантики этого глагола в говоре и рус. учumb, cp. n'em'eck'emu jenzykov'i ucyli 'немецкому
} 
отношению к таким примерам, как curka pracuje nauncyćelkum a syn $k$ 'erofcum 'дочь работает учительницей, а сын шофером' - твор. п. ${ }^{3}$ (в общепольском именная часть подобного сказуемого вводится при помощи союза jako); тем более не относится к управлению выражение творительным падежом обстоятельства меры при форме сравнительной степени наречия (dv'ema latam'i puźn' $i$ 'двумя годами позже' - общепольск. $d w a$ lata później $\left.{ }^{4}\right)$. Не связаны с нарушением управления и случаи замены посессивной конструкции глагола 'иметь' + вин. п. заимствованной из РЯО конструкцией глагола ‘быть’ + род. п. с предлогом u (ци mn'e jes jedyn syn 'у меня один сын' наряду с mum cvoro з́еći 'у меня четверо детей'), а с нарушением согласования по числу - примеры употребления «внечисловой» формы глагола 'быть' в настоящем времени (uи mn'e svoje sv'itry jes 'у меня свои свитера есть'): скорее это проникшая из РЯО особенность морфологии данного глагола, точно так же, как фактом морфологии одушевленных существительных, в том числе женского рода, включая названия животных, является обязанная влиянию РЯО возможность совпадения

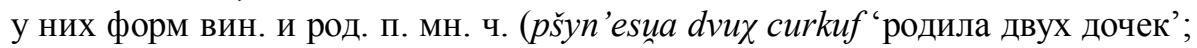
pas ov'ec 'пас овец' - но и m'ou curk' $i$ 'имел дочерей', čšmmal'i my krovy, śv'in'e, u्रofcy 'мы держали коров, свиней, овец'). Помимо этого автором отмечено распространение в ВСП русских предложно-падежных конструкций и просто русских предлогов:

1) пространственных типа $f$ tajge 'в тайгу' - общепольск. do tajgi ;

2) временны́х типа ро subotam 'по субботам', ${ }^{, 6}$ za lato 'за лето', posle vojny 'после войны ${ }^{\text {; }}$;

языку учили' с дат. п. и ucy pol'sk’i ‘учит (= изучает) польский’ с вин. п. [8. С. 204]. Примечательно, что соотносительный глагол копирует двоякую русскую сочетаемость вместе с семантикой и в ЗСП, а также в ЗСЧ, ср. с вин. п. Rosyjan'e? a ucita pol'sk'i? 'русские? а учите (= изучаете) польский?'; ve škole sme učili n'emeckej 'в школе мы учили (= изучали) немецкий' и т. п.

3 Аналогичная сочетаемость глаголов со значением 'работать' с твор. п. под влиянием РЯО закрепилась также в ЗСП и ЗСЧ, ср. соответственно óna robiuna ućiteln'ico и ona uš robotala učitelkou 'она работала учительницей'; unona vračem d'elá 'она врачом работает'.

${ }^{4}$ В других изучаемых говорах при обозначении различия между двумя сравниваемыми по величине предметами используется заимствованная из РЯО конструкция с предлогом na, сp. в ЗСП ојс́еc buu na šesnašč́e lat starsy 'отец был на 16 лет старше' [3. C. 188], в ЗСЧ na pjet let je mlatši neš ja 'на 5 лет моложе меня'.

${ }^{5}$ При этом употребление предлога $n a$ в таких сочетаниях, как na kopaln’ $i$ 'на/в шахте' или na V'eršyn'e 'в Вершине', безоговорочно относимое автором за счет влияния РЯО, вполне может иметь исконно польские корни. Ср. то же в ЗСП: иn robžu $f$ sofxoźe

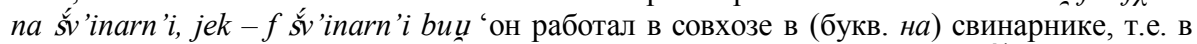
свинарнике был'; Aleks'androfka fsa na N'ikot'ajefce bili, tak jek tata (...) tš́s braty jego bili $v$ N'ikot'ajefce 'Александровка вся бывала в (букв. нa) Николаевке, так как папа... три брата его были в Николаевке' [3. С. 179, 182]; в ЗСЧ $f$ tom Molotovu и na Molotovu 'в (этом) Молотове' (в 1937-1957 гг. название с. Иртыш Омской обл.).

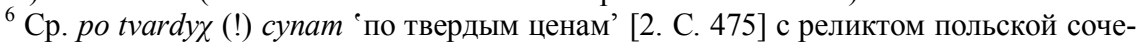
таемости предлога ро, здесь - не во временно́м значении, с местн. п. прилагательного, 
3) временны́х с числительными типа $f p$ ’in'źgoźin ‘в пять часов', аналогично v il'e ‘во сколько?' (общепольск. o piątej, o której):

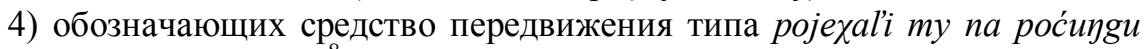
'мы поехали на поезде' ${ }^{8}$ при сохранении польской конструкции с беспред-

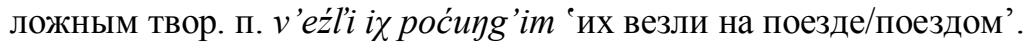

Фиксируются также заимствованные из РЯО беспредложные конструкции типа ұoruvounem grypym ‘я болел гриппом' (в данном случае наряду с польской na toto ұoruvou ‘ этим он болел').

В сложном предложении исследовательница указывает на такие русизмы, как разделительный союз ili ... ili (наряду с польским cy ... cy) и калькированный - с модификацией - союз причины potak'imu že 'потому что' (наряду с польск. $b o$ ).

Е.В. Ступинский в диссертации о ЗСП затрагивает только «элементы синтаксиса» в главе, посвященной в основном лексике [3. С. 126-127]. Также и он приводит примеры употребления проникающих из РЯО пространственных предложно-падежных конструкций типа jeźźiula $f$ Polśe 'ездила в Польшу' и твор. п. при глаголе со значением «письменной реги-

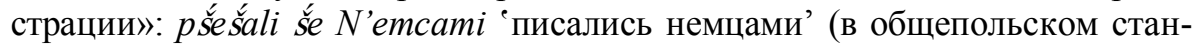
дарте именная часть сказуемого и в этом случае вводилась бы союзом jako $)^{9}$. В сложном предложении автор обращает внимание на адаптированный русский союз причины 'потому что', выступающий в ЗСП в виде potemu со (при аналогичном вопросительном слове росети 'почему'), и в том же ряду на союз цели cobi 'чтобы' и простой союз со в придаточных типа dobze co pś̀j jexali 'хорошо, что приехали' (в общепольском стандарте $\dot{z} e)$. На это можно возразить, что употребление союза со - наряду с zе и

что для существительного в дат. п. Н. Е. Ананьева трактует как фонетикосинтаксическую адаптацию.

${ }^{7}$ Точно так же в ЗСП и ЗСЧ проникли русские предлоги после, во время и временной союз пока, вытеснив, полностью или частично, соответствующие исконные служебные слова.

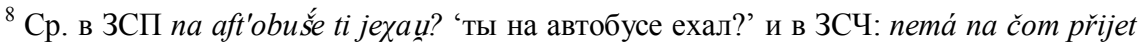
'ей не на чем приехать', jela sem tam na vlaku 'я ехала туда на поезде' и даже já sem prilitla dř́v na letadlu 'сначала я прилетела на самолете'.

${ }^{9}$ Полное высказывание информантки Ступинского в завершающей его работу подборке текстов содержит также иной вариант выражения именной части сказуемого при том же глаголе (с русским союзом как = польск. jako): mi pš́š́ali š́e fš́stiste na ojca $N$ 'emcami... mi to jus n'i, a starsi źeći pš́esali še kak N'emce, a nas to pšesali Polakam 'i 'мы все писались по отцу немцами; мы-то уже нет - старшие дети писались как немцы, а нас писали поляками', а высказывание другой диалектоносительницы - вариант с существительным в им. п. при этом глаголе: a mi f̌́se Polaki... u mn'e $i$ tak'e క́eći š́e pśsiso Polaki 'а мы все поляки, у меня так и дети пишутся - поляки' [3. С. 228, 166]. Аналогично в материалах нашей экспедиции 2013 г.: on š́e napśisau Polak'em, $i$ u n'ego vojennyj b'il'ed byun Polak (...) $i$ on xćau bić Polak'em i zapśsisau š Polak 'он записался поляком, у него военный билет был (с записью) - поляк, и он хотел быть поляком и записался - поляк'. Любопытно, что форма им. п. в наших записях встретилась и в составе сказуемого с глаголом 'работать': vopš́m unot robžuu m'izan'zator 'в общем, вот он работал механизатор(ом)'. 
даже ize - в придаточных изъяснительных предложениях было известно и мазурским говорам на их исходной территории, ср.: $i$ śe pali $d \dot{o} m<\ldots>i$ suiso, co ón tak vřesci, ze ma do stodouni śe dostać 'и горит дом... и слышат, что он кричит, чтобы в амбар угодило (букв. что должно угодить)'; ojcove suova, co ón ma znajómó vźóść 'отцовы слова, что он должен знакомую взять (в жены)' и moźi ц厶, ize takó zonk'e ma vźość, jeko jo zna 'он говорил, что такую жену он возьмет, которую он знает' [19. С. 72-74]. В то же время Ступинский верно подметил наблюдающееся в ЗСП копирование строя ряда русских фраз, в частности включающих со в качестве вопросительного местоимения в функции частицы и оптативные частицы с элементом $b i$ и без него, например: da ti co?! 'да ты что?!'

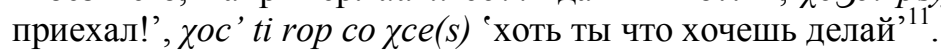

По отношению к ЗСЧ попытка обозначить некоторые более общие линии развития его синтаксической системы в условиях контакта с РЯО была сделана в моей статье 2013 г. [13. С. 134-135]. С определенными изменениями выработанная тогда схема представляется применимой и при сопоставительном описании синтаксических особенностей ЗСЧ (а также СКЧ) и польских говоров в Сибири. На материале ЗСЧ были выявлены следующие тенденции, иллюстрируемые ниже отчасти новыми примерами из того же идиома:

1) вытеснение посессивных конструкций с глаголом 'иметь' конструкциями русского типа с глаголом 'быть' и именем обладателя в род. п. с

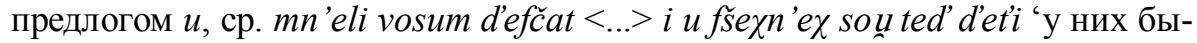
ло (букв. они имели) восемь девочек... и у всех теперь дети'; jak ti prázn’ini soụ u školácu... 'когда у школьников каникулы...' и т. п.;

2) некоторое ослабление тенденции к заполнению позиций объектных актантов глагола (О) анафорическими местоимениями (uotkril kolbasnyj

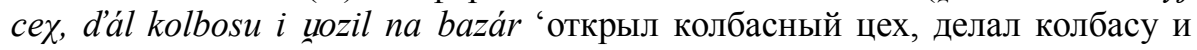
возил $(\mathrm{O}=\varnothing)$ на базар' наряду с üon hledá tadik nevj'estu - vem ji, já ti ji dám 'он тут ищет невесту - возьми (букв. еe, $\left.\mathrm{O}=\operatorname{Pron}_{\mathrm{acc}}\right)$, я тебе еe $\left(\mathrm{O}=\mathrm{Pron}_{\mathrm{acc}}\right)$

${ }^{10}$ Такое же употребление со зафиксировано в СКЧ под Новороссийском: Ti co! To nesmn 'elo bejt! 'Ты что?! Это запрещено было!'; несколько иное - в ЗСЧ: Tak vi co, pješki, ja sem slišel, pješki ұcete... 'Так вы что, пешком, я слышал, пешком хотите?..'; Nu co, jak met? <...> Co vi nej'iste (!) met? 'Ну что, как мед? Что вы не едите мед?'; ji jak co,

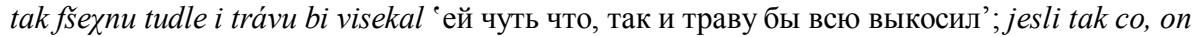

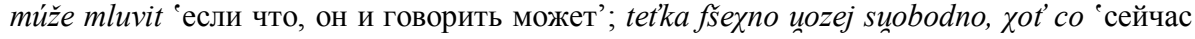
всё свободно возят, хоть что'.

${ }^{11} \mathrm{Cp}$. предложения с теми же заимствованными из РЯО оптативными частицами в

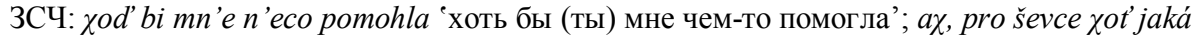
'ax, для сапожника - хоть какая' (из песни). Русизм ұot' здесь выступает и в основной для него в языке-источнике функции: в качестве единственного известного данному говору уступительного союза (cp. ұot'i nemám hdi - pjet minut, no stejn'e já posedim 'хоть и некогда мне - пять минут, но я все равно посижу'). Для польских говоров уступительный союз ұос́, по-видимому, следует считать исконным, однако в качестве частицы эта лексема в польском языке не функционирует. 
дам $\left.^{12}\right)$ при сохранении тенденции к подстановке местоимения в позицию формального субъекта предложений так называемого типа es-Satz (vot takoví to bilo u nás ‘вот так (букв. такое это) у нас было’ и т.п.);

3) экспансия безличных конструкций русского типа, в частности, с заимствованным модальным предикативом nado/nada, с которыми сосуществуют чешские конструкции с личными формами модальных глаголов, в том числе выступающими в обобщенно-личном значении, как в РЯО, cp. musíś jet-a kam pojedeš, jesli já nohi mám kaleki, a jet nada 'ты должен/должна ехать, а куда поедешь, если у меня ноги - калеки, но ехать надо';

4) конкуренция конструкций с возвратным компонентом se и русского типа обобщенно- и неопределенно-личных предложений с формами 2-го л. ед. и 3-го л. мн. ч. глагола, например: uwařej se kartoški <...> a potom takovejmadle kouskama t'esto ud'eláš i takovej jak listejček nařežeš, knedlički hod'iš a sliukki, d’iš se prepoúščej <...> prepustís tima sli unkama '(c)варят картошку (букв. сварятся картофелины), а потом вот такими кусочками тесто сделаешь, такой как бы листочек нарежешь, клецки бросишь - и сливки, когда припускают (букв. припускаются), то припустишь с этими сливками'; v dvanáz hod’in noci zd'elávali vjenek... vot posle, jak se zd'elá ujenec, pat'om paž'alusta 'в 12 часов ночи снимали венок... вот после, как снимут (букв. снимется) венок, потом пожалуйста'.

Второй группы явлений я коснулся в сопоставительном плане в статье [20. С. 186-187], где констатировал, что проблема (не)употребления анафорических местоимений актуальна только для чешских говоров в России, но не для польских, изначально близких в данном отношении к РЯО, подтвердив это примерами из ЗСП типа ұleba mama nap śece, nam da s sobo 'мама хлеба напечет, даст $(\mathrm{O}=\varnothing)$ нам с собой'. Немало таких случаев отмечается и в ВСП, ср.: Janeg, brad močšy <...> zaхorovou. <..> Do bolnicy potym juž unuv'eźl'i, to puźno byuno 'Янек, младший брат, заболел... В больницу потом уже отвезли $(\mathrm{O}=\varnothing)$, да поздно было’ [4. С. 181]. Ввиду этого указанная черта ниже не рассматривается, как и тип предложений es-Satz, не представленный в польских говорах Сибири (хотя известный польским диалектам, см. [21. С. 61]).

В дальнейшем изложении я сосредоточусь на разнообразно проявляющейся в переселенческих западнославянских говорах Сибири конкуренции личных и безличных, глагольных и именных конструкций, в том числе с инфинитивом, причастиями, посессивных и др., а также копулятивных и некопулятивных (связочных и бессвязочных) предложений.

${ }^{12} \mathrm{C}$ точки зрения чешского языка, включая его диалектные манифестации в Чехии, в этой фразе недостает указания на тождественность адресата обоих действий субъекту при помощи местоименного происхождения частицы $s i$ 'себе'; с другой стороны, вторая ее часть с дважды употребленным местоимением в вин. п. ( Pron $\left._{\text {acc }}\right)$ по-русски естественнее звучала бы бери, даю! 


\section{Инфинитивные конструкции: модальные, целевые, оптативные и др.}

Распространение русского типа конструкций с инфинитивом в СКЧ под Новороссийском и Анапой прослеживалось в статье, написанной мною совместно с Д.К. Поляковым [22. С. 330-335], и в работе последнего [23. С. 141-142]. На сравнимую с чешской конкуренцию личных, с модальными глаголами, и безличных конструкций с модальным предикативом и инфинитивом в ЗСП было обращено внимание в моей статье [20. С. 181-183]. Впрочем, сравнение показывает, что в польских переселенческих говорах,

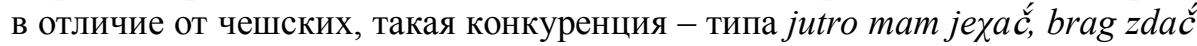
p'ašporty na v'ize ‘завтра я должна ехать, надо сдать паспорта на визы’ в ЗСП или čša byùo śe unucyć, to my muśeli ćuggnun'ć sank’i 'нужно было учиться, вот мы и должны были тащить санки' в ВСП [4. С. 182] - является наследием исконного диалектного состояния. Влияние РЯО сказывается здесь только в случаях употребления прямых заимствований, в том числе адаптированных, например, в ЗСП: A jek podukti vam, n'e nužno kupać? 'A как продукты, не нужно вам покупать?'; Muśseli š́e potč́in 'ać<...>F ́s̆ako, po

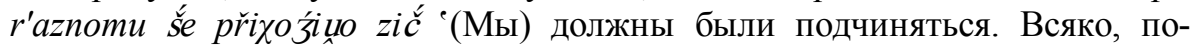
разному приходилось жить'; в ВСП: puźn'i śe pšyšŭo izza tvavmy unun'ś 'позже пришлось из-за травмы уйти' [Там же. С. 179].

То же касается целого ряда других типов инфинитивных конструкций, примеры которых из СКЧ, приведенные в [23], находят соответствия и в ЗСЧ; ср. особенно употребление инфинитива со значением цели: a vobjedi vona ešce vezla <...> nu lid'um do pole jíst 'и обеды она еще везла - ну, людям в поле есть', в том числе в придаточном предложении: tet'kej molod'oš utiká unocát', abi ned'elat 'сейчас молодежь бежит отсюда, чтобы не работать', а также в придаточном условном или развившемся из такого придаточного оптативном предложении: jesi unotat' jet $k$ n'im, to <...> v'ízu votkrejvat nada 'если отсюда ехать к ним, то визу открывать надо', a dis

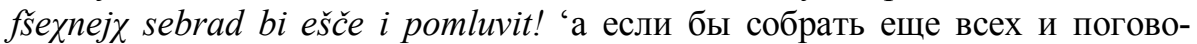
рить!', vot Tondu bi vzat ešče Bartošovího! 'вот взять бы еще Тонду Бартоша!' Невозможные в чешском языке, подобные конструкции, напротив, либо обычны в польском языке (инфинитив в придаточных предложениях с союзами $a b y / z \dot{z} b y$ 'чтобы’, gdyby ‘если бы’ и оптативных с частицей $o b y$ 'о если бы'), либо известны польским диалектам (ср. śekyra dževo rombać 'топор дрова рубить', vozom do m'asta spšedać ‘возят в город продать' [21. C. 63]). Тем самым, если и признавать русизмом употребление инфинитива в случаях типа $a$ n'itk'i to n'i ma ap'aźzamotać 'а нитки-то нет опять замо-

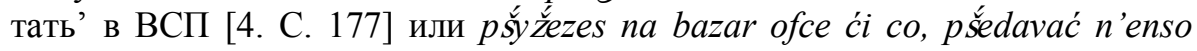
'привезешь на базар овцу или что, продавать мясо' в ЗСП [3. С. 172], то это заимствование, легшее на диалектную почву. Уже довольно заметный отрыв от нее в силу выражения семантического субъекта действия в придаточном предложении существительным в дат. п., впрочем, демонстрирует

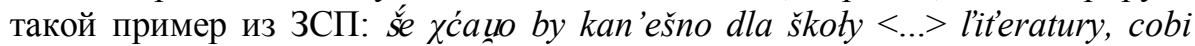
mozna biųo źećam z_interesom š́ zajmivac' 'хотелось бы, конечно, для шко- 
лы литературы, чтобы детям можно было с интересом заниматься' [Там же. С. 236].

Некоторые типы инфинитивных конструкций в анализируемых польских идиомах, однако, обязаны своим появлением исключительно влиянию РЯО. Многие из них представлены и в чешском переселенческом говоре, ср. особенно: jek muйić ‘как сказать’ в ЗСП и jak uám řict 'как вам сказать', tak po česki ř́ct 'так по-чешски сказать' в ЗСЧ; sp śevać sp š́evali m'ołod'oś ‘петь молодежь пела' в ЗСП [Там же. С. 159], b’iź noz n'igdy n'e b'ili 'бить нас никогда не били' в ВСП [4. С. 184] и von'i jej votv'ečaj na ruskim a rozumit fšecko rozumí 'они отвечают ей на русском, а понимать всё понимают' в ЗСЧ. Отдельные типы отмечены, напротив, только в одном идиоме: например, частый в ЗСП тип mn'e nazivać Tas'a Šyšk'o 'меня звать Тася Шишко’ [3. С. 225].

\section{Конкуренция обобщенно-, неопределенно-личных предложений и возвратных конструкций}

Расширенное под влиянием РЯО употребление обобщенно-личных предложений со сказуемым в форме 2-го л. ед. ч., подобное фиксируемому в ЗСЧ, констатировала для ВСП Митренга-Улитина, cp. ty k'edy unum'iroš, to čša pšedać drug'imu 'когда ты умираешь, надо передать (свои умения) другому' «вместо типично польской безличной формы» (в данном случае umiera się), как это сформулировано в ее монографии [4. С. 121]. При этом в прилагаемой автором подборке текстов удается найти всего один реальный пример конкуренции конструкций с русского типа формой 2-го л. ед. ч. и с польской возвратной формой 3-го л. ед. ч.: Jak urok, čša uonucke na copke uoźoć, no popluje śe čšy razy. A to ješše čšba do gorcka naloć vody $<$...> Ji uno tym śe unobečšeš, tum vodum, popluješ... 'Если сглаз, надо портянку надеть на шапку, ну и сплюнуть (букв. сплюнется) три раза. А еще надо в кружку налить воды... И вот этим оботрешься, этой водой, сплюнешь...' [Там же. С. 183]. В остальном с такими возвратными конструкциями в ВСП конкурируют конструкции с неопределенно-личными формами 3-го л. мн. ч. и с личными формами глагола, ср.: Uu nos tak'e v'elk'e

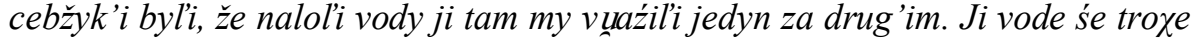
jino dolyvauno, n'e m 'in'aùo śe tak, jak teros, co śe pod dušym myje 'У нас были такие большие лохани, куда наливали воды, и мы залезали туда один за другим. И воду только немного доливали, не расходовали так, как сейчас, когда под душем моются' (букв. доливалось, не расходовалось, моется); Rob'ili že my darym toto. A tero unot co to pšyšuno, že tyn, p'ens'ije m'i jakum dajum. Rob'iú śe, rob'iúo <...> No pšerob'iulam caun svuj v'ek, a teroz muv'e $<\ldots>$ N'e v'im, jak śe byźe dali žyú 'Работали мы даром. А сейчас вот как вышло, что это, пенсию мне какую дают. Работала, работала (букв. работалось), проработала я весь свой век, а теперь говорю... Не знаю, как дальше буду жить (букв. будет житься)' [Там же. С. 179, 180]. Аналогично в ЗСП: r'eš́li Jenis "ej ženksy zrobắć i to d'er'evn'e zatopš́c <...> i ubrali te d'er'evn'e, te 


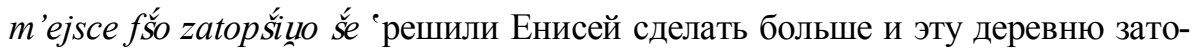
пить... и убрали эту деревню, это место всё затопили (букв. затопилось); $i$ tera mn'e <...> zrobžuu tak'e tuk'i šano, a ono pozne, "on'e robźli jesce one $o b v$ 'aune biuno, jek te tuk'i še skren'ćino 'и сейчас он мне сделал такие тюки сена (букв. сено), а оно позднее, когда они делали, оно еще вялое было, когда те тюки связали (букв. связалось)' [3. С. 163, 212-213].

Как показывают эти примеры, в ВСП и ЗСП в целом сохраняется структурная и семантическая специфика польских возвратных безличных конструкций, отличающая их от соотносительных конструкций чешских и русских, которые также разнятся между собой, однако по крайней мере у прямообъектных глаголов имеют схожий пассивный характер: объект-пациенс занимает позицию подлежащего, и возвратная форма согласуется с ним по числу и иным релевантным категориям ${ }^{13}$. Этого не происходит в польских конструкциях, ср. в ВСП vode (вин. П. ед. ч.) se dolyvaluo, в ЗСП te tuk'i (вин. п. мн. ч.) še skren'ćino при форме 3-го л. ед. ч. ср. р. в обоих случаях, в отличие от потенциальных соответствий в рус. подливалась вода или - с заменой вида - связывались тюки. Иногда, однако, из-за омонимии форм вин. и им. п. бывает непросто отделить наследие исходного диалекта от русизмов. Проиллюстрирую это тремя извлечениями а) из ВСП, б) и в) из ЗСП:

a) no a toto tak barzo juš śe n'e pam'into, bo to uš tyle lot pšešŭo 'но это уже не очень-то и помнится, ведь уже столько лет прошло' [4. С. 180], где можно видеть как польскую конструкцию, так и калькированную русскую;

б) mn'e tera fspomn 'ina š́ fśsistk'e unot moje d'ectvo 'мне вот сейчас вспоминается всё мое детство' [3. С. 226], где русское происхождение конструкции выдает выражение семантического субъекта действия формой дат. п. местоимения;

в) tera ja juz zabaciuna po polsku <... tak jeg bi śe robžiuno, to bi trosk'e śe $f$ spom 'inauno 'сейчас я уже забыла польский... вот если бы работала, то понемногу бы вспоминала (букв. работалось, вспоминалось)' [Там же. C. 150] - здесь налицо типично польская конструкция с возвратными формами безобъектного и безобъектно употребленного глаголов.

В то же время в ЗСП встречаются примеры необычной для польского языка (включая диалекты, в том числе мазурские) возвратной конструкции пассивного типа с трансформацией объекта переходного глагола в субъект (подлежащее), которая только в отдельных случаях может быть возведена напрямую к РЯО, ср. в материалах нашей экспедиции 2013 г.: $i$ p š́esn'e

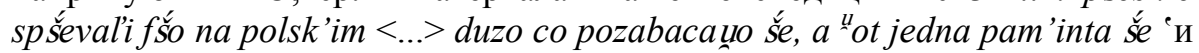
песни мы пели все на польском... многое позабылось, а вот одна помнится'. В других случаях в такой конструкции находим возвратные формы глаголов: либо совершенного и несовершенного вида рядом: od gźe š́no

${ }^{13}$ Впрочем, в записях СКЧ под Новороссийском встретился неожиданный для чешского языка (включая диалекты) пример возвратной деагентивной конструкции «польского» типа, без трансформации прямого объекта переходного глагола в подлежащее: vin'ici se kopá metr ‘виноградник копают (букв. копается + вин. п.) на метр' [22. С. 333]. 
skosone, tam te po tym kớén'u tedi taka mauna trafka... jek ona skośi śe, a rèncan'i śe kośi to vopśs maúa trafka <...> i tedi te $i$ te puaskunk'i <...>

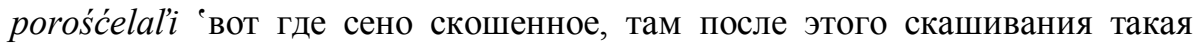
маленькая травка... когда ее скосят (букв. она скосится), а маленькая травка вообще-то руками косится, вот тогда посконь расстилали', либо только совершенного вида, ср. из записей Ступинского 2002-2006 гг.: i na

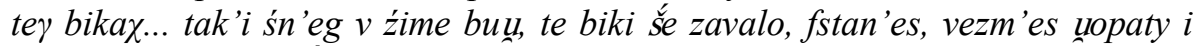
odvalas, droge robžis tem bikam 'и на быках... такой снег зимой был, этих быков завалит (букв. эти быки завалятся), встанешь, возьмешь лопаты и отваливаешь, дорогу прокладываешь этим быкам'; $u$ mn'e za śćano m'edig

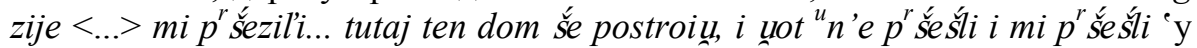
меня за стеной живет женщина-медик... мы прожили... тут этот дом построили (букв. построился), и вот они перешли (сюда), и мы перешли' [3. С. 161, 186]. Возможно, подобные примеры отражают периферийное развитие конструкции, заимствованной из РЯО, под влиянием структурно отличной от нее польской конструкции, не знающей ограничения глаголов по виду.

\section{Причастные конструкции}

Во всех рассматриваемых идиомах распространены также частично синонимичные описанным конструкции со страдательными причастиями. В первую очередь обращает на себя внимание изредка отмечающееся в ЗСП употребление кратких причастных форм им.-вин. п. ед. ч. ср. р. на -nо без глагола-связки, не тождественных типичным для польского (литературного) языка неопределенно-личным формам прошедшего времени на no/-to ${ }^{14}$. В примере tera on dostau drugo m'etrike, to kazano, cu un N'em'ec 'сейчас он получил другую метрику, там сказано, что он немец' [3. С. 167] выступает явный русизм (если не украинизм): польск. kazać имеет значение 'велеть', Сложнее объяснить форму на -no во фразе Čajkofski Janek <..> on pš́isau i Brik Stašek <..> po rusku pš́isano, no duzo n'e davali, ratko pśsisali 'Чайковский Янек, он писал, и Брик Сташек... по-русски писали (букв. писано), но много писать не давали, писали редко' [Там же. С. 190]:

${ }^{14}$ Исходным для ЗСП говорам, как и другим польским диалектам, такие формы, впрочем, и не были известны. В мазурских текстах из сборника К. Нича краткие страдательные причастия ср. р. в сказуемом встречаются всегда в конструкции с глаголом 'быть', которая может иметь и активное значение, cp. tag biuo spš́vano 'так пели', $i$ duzo jest tamo luźi zebrano ‘и много народу там собралось’ [19. С. 57, 72].

${ }^{15}$ Такой же русизм, повторенный дважды (в первом случае - с русской редукцией

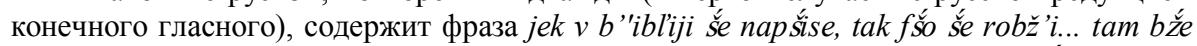
nар'erŭo p'isane: весь мир будет напоен вином - jest'... i tip "'er, tam napš́isana, tam napš́sano co jesce... 'как в Библии написано (букв. напишется), так всё и делается... там перво-наперво написано... так и есть... а теперь там написано что еще...', в начале которой после необычной возвратной формы глагола $\mathrm{CB}$, возможно, представлена единичная в записях ЗСП мазурская форма пассива настоящего времени, являющаяся калькой немецкой формы типа wird geschrieben (см. [20. С. 184]). 
семантически она отличается и от польской литературной pisano 'писали' с подразумеваемым неопределенным субъектом, и от рус. писано. Вероятно, также и здесь мы имеем дело с периферийным употреблением формы, заимствованной из РЯО, в значении польской возвратной формы pisato sie, допустимой в данном контексте.

В остальном в анализируемых диалектах возможны, с одной стороны, краткая (ср. р. ед. ч. в ЗСП) и полные формы страдательных причастий в составе сказуемого с глаголом-связкой, а с другой - только полные формы в функции сказуемого без связки.

Конструкции первого типа во всех говорах могли бы считаться исконными, хотя примеры их часто носят заметный отпечаток структурно совпадающих русских соответствий ${ }^{16}$ (в частности, и лексический), ср. в ЗСП: $v$ b'ibliji, tam co je napš́sano ‘в Библии, там что (букв. есть) написано'; tedy jesce tag biuي pevno zapreśćono 'тогда еще такое было, наверное, за-

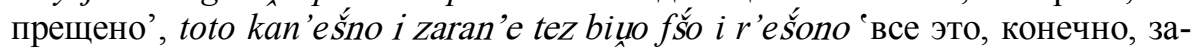
ранее было решено'; из записей Ступинского: tera tojs' n'e nas dom, jest on pšedany 'теперь это уже не наш дом, он продан (букв. есть проданный)'; duze nari bili drevn'ane zrobžone 'большие нары деревянные были сделаны'

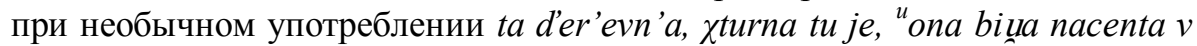
naćal'e tego v'eka 'эта деревня, которая тут есть, она была основана (букв. начатая, т. е. началась) в начале того века' [3. С. 178, 165, 215]); в ВСП: tam nary tak'e byuny i dran'e tak'e byuny pośśelane 'там были такие нары, и такие тряпки были постелены', kartofle by цy vykopane 'картошка была выкопана'; а также pšoźi by цy košule z b'ouego tovaru šyte ‘раныше рубахи из белой ткани шили (букв. были шитыле) [4. С. 177, 182]; в ЗСЧ bilo zapreščení sem do Ros 'iji co libo unozit ‘было запрещено сюда, в Россию, чтолибо ввозить'; $i$ na svadbu tam lid'i, hdo je bil pozvanej, von'i pomohali druh druhu... vot jesli ja sem nn'ekomu pozvana, já musím vodnist maso n'ákí... ‘ и на свадьбу люди, кто был приглашен, они помогали друг другу... вот если я к кому-то приглашена, я должна отнести что-то мясное...'; bila taková

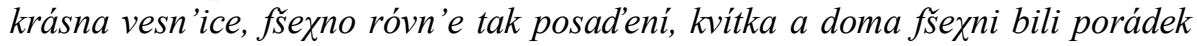
vobilení, vobarvení 'была такая красивая деревня, все было так ровно посажено, цветы, и дома были всегда побелены, покрашены'; tat'inek bil i na fronte... nu, řikaj že unon bil zrouna na unostok uzzatej 'папа был на фронте говорят, сначала его на восток взяли (букв. он был взятый)'.

Второй тип конструкций с причастиями, вероятно, развился под влиянием русских говоров Сибири. Речь идет о таких случаях, как:

\footnotetext{
${ }^{16}$ Их соответствиями, за исключением оборотов с краткими причастиями ср. р. типа было запрещено, несомненно, будут не столько литературные, сколько диалектные конструкции с полными формами причастий, такие как После войны построили (мост), в войну сожганой был [24. С. 157]. В примерах из ЗСП и ЗСЧ ниже формы ж. р. на -a, исходя из системных соображений, следует признать полными: давняя долгота $-\overline{\mathrm{a}}<$ *-аја здесь по фонетическим причинам не отражается (что, напротив, наблюдается в ВСП в форме postav'uno с конечным -o <-ā).
} 
1) в ВСП a tero čšé́o škouna postav'uno na tym m'ejssu 'а теперь третью школу построили (букв. третья школа построенная) на этом месте' [Там

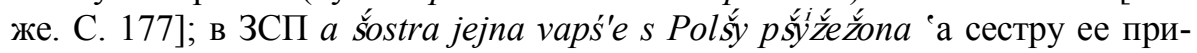
везли вообще из Польши (букв. сестра ее привезенная)'; ср. также омонимичную активную причастную конструкцию в ЗСП rozony ja za žyku Jen'is" 'ej, śe ro ̌̌u dvaźeśća drug'im roku 'родился (букв. рожденный) я за рекой Енисей, в 22-м году родился’ [3. С. 200, 243, 245] и в ЗСЧ narozená sem $v$ lednu padesát třetỉho roka 'родилась (букв. рожденная) я в январе 53-го года' либо даже mí rod'iče rožd'oní sou tedik 'мои родители тут родились (букв. рожденные)' с полностью заимствованным из РЯО причастием, оформленным только чешским адъективным окончанием, но с внедрением в конструкцию формы настоящего времени глагола-связки;

2) в ВСП vele Zurka n'e śecune, an'i kartofle n'e plev'une, букв. у Зурека не кошено и картошка не полота (т. е. Зурек этого не сделал, и никто другой за него тоже) [4. С. 183]; в ЗСП $u$ nas f́cugk opłacone na goźine <...> $i$ tedi do nas jus pš́ýxoźi ta_muzyk'ant 'мы всякий раз платим (букв. у нас всегда оплачено) за час, и тогда уже к нам приходит музыкант' [3. С. 184].

Подтип 1 в ВСП и ЗСП может иметь также собственно польские корни, cp. Tug bóúa škoua, ta vypo lönou ‘ Тут была школа, ее сожгли (букв. она сожжена)' [21. С. 80]. В то же время вряд ли случайно его сходство с русским диалектным типом Корм-та весь спасёнай [24. С. 157], который широко бытует и в говорах Сибири. Примечательно совпадение приведенных выше сообщений носителей ЗСП и ЗСЧ о рождении (своем и родителей) с примером М.А. Харламовой из аб'аџкава ра'ёна я р'ождена [17. С. 82], в котором, однако, выступает краткая форма причастия.

Подтип 2, присущий только польским идиомам в Сибири, видимо, отражает влияние частотной, особенно в северо-западных русских говорах, «конструкции с кратким страдательным причастием, образованным от переходного глагола в его непереходном (абсолютивном) значении», типа вон у ей настирано да развешано [24. С. 154]. Хотя в этой конструкции «посессивное сочетание $y+\mathbf{P}$ » выступает, «как правило, с недифференцированным значением деятеля и обладателя результата действия», встречаются случаи типа с той кучи у кого-то взято (= кто-то взял), когда им выражен субъект действия [Там же. С. 154-155]. Оба эти значения демонстрируют примеры из ВСП и ЗСП выше, которые отличает от диалектных русских употребление полных, а не кратких причастий, но объединяет с ними наличие в принципе не свойственного западнославянским языкам и диалектам «посессивного сочетания $y+\mathbf{P} »$.

\section{Конкуренция конструкций esse- и habere-типа}

Можно сказать, что последний подтип рассмотренных причастных конструкций представляет частный случай наблюдаемого во всех изучаемых идиомах вытеснения посессивных конструкций с глаголом 'иметь' конструкциями русского типа с той или иной формой глагола 'быть' (включая 
нулевую) и именем обладателя в род. п. с предлогом $u$ или, реже, в дат. п. Выше были приведены некоторые примеры конкуренции названных конструкций в ЗСЧ и ВСП (последние по [4. С. 118]), к которым стоит добавить примеры с наречием в составе той и другой конструкции: cyśśstko mum и u্রи mn'e tak cyśśutko jes ‘у меня (так) чисто’ [Там же. С. 183]. Аналогичная конкуренция имеет место в ЗСП, ср. пример контаминации обеих конструкций: "ِ ${ }^{\prime} n$ 'au dva sini u n'ego bili, букв. 'он имел два сына у него были', а также $f$ S̆́ и nas jest 'всё у нас есть' и mami fŕststk'ego vdovol . 'всего у нас вдоволь', jesli u uas cas jest 'если у вас есть время' и $n$ 'edužo casu ma 'у нее немного времени' [3. С. 158, 201-202, 231, 243]. В конструкции русского типа здесь довольно часто отмечается пропуск глагола 'быть' в настоящем времени: $u$ mn'e tlo jeden brat 'у меня только один брат', pš́en'ć

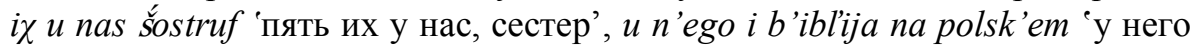
(есть) и Библия на польском' [Там же. С. 158, 185]; в наших записях 2013 г.: p'ens'ija u mn'e tes n'eduza 'пенсия у меня небольшая'.

Помимо того в обоих польских говорах конкурируют конструкции, обозначающие возраст, с глаголами 'иметь' и ‘быть' (в настоящем времени последний в ЗСП также обычно опущен), во второй из которых семантический субъект выражен формой дат. п.; например, в ВСП: Moja matka pšyjexaùa s Polsk'i. M'aùia jedynaśśse lot <...> ji $f$ štyrźestym źev'untym

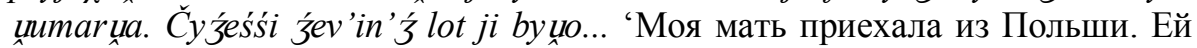
было (букв. она имела) 11 лет... и в 46-м умерла. 49 лет ей было’

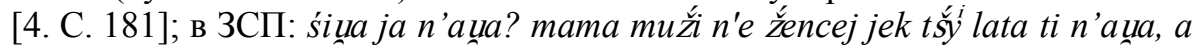

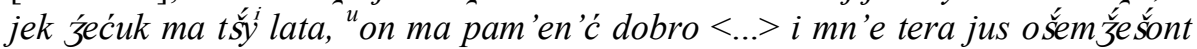
$d v a$, ośem ̌́e śont tš́é $i$ rok 'сколько мне было? мама говорит, не больше трех лет тебе было, а когда ребенку три года, у него хорошая память (букв. $я, \mathbf{m b l}$ имела, он имеет)... а сейчас мне уже 82, 83-й год', nasej cerkv'i ju_sto 亏̌́e śen 'ć lat ‘нашей церкви уже 110 лет’ [3. С. 192-194] и т. п.

В ЗСЧ конструкция с глаголом 'быть' и выражением семантического субъекта формой дат. п., обозначающая возраст, является исконной; вторичное русское влияние на нее иногда выдает разве только инверсия числительного и существительного при указании на приблизительность (let šest mi bilo ‘лет шесть мне было') и употребление при числительных 2-4 и составных с ними формы род. п. мн. ч. существительного и ед. ч. глаголасвязки, что, впрочем, возможно и в современном чешском языке: On je mladej, jemu je třicet tři roku, třicet štiri daže 'Он молодой, ему 33 года (букв. годов), даже $34^{, 17}$. Пропуск глагола ‘быть’ наблюдается здесь лишь изредка при повторе, в случаях эллипсиса, и не в качестве системной черты; ср. в прошедшем времени: $n u$, ji bilo... jesli unona je dvacet prun'iho roka, to jí sedum let... to bil jakej, dvacet vúsmej rok 'ну, ей было... если она 21-го года, то ей 7 лет... это какой был - 28-й год'.

\footnotetext{
${ }^{17}$ Аналогичные особенности синтаксиса числительных в СКЧ под Новороссийском описаны в [23. С. 142-143].
} 


\section{Копулятивные и некопулятивные предложения}

Неэллиптическое опущение личных форм глагола-связки 'быть' в предложениях, относящихся к плану настоящего (и вневременных), под влиянием предложений аналогичной структуры, характерных для РЯО, проявляется неравномерно в чешском и польских говорах Сибири. В ЗСЧ относительно регулярный пропуск связки ограничивается лишь предложениями отдельных типов. Таковы, в частности, предложения с модальным предикативом nado/nada, о которых была речь выше, и с оценочными наречными предикативами t’eško 'трудно' (но также со связкой: t’eško je), pjekn'e 'хорошо', špatn 'e 'плохо' в восклицании Oj, špatn'e nám! 'Ой, плохо нам!'. Предложения иных типов без связки нечасты: Mi uš starí, tak nemožem tak spivat pjekn'e 'Мы уже старые, поэтому не можем так хорошо петь'; Nu jak vi tadi? 'Ну как вы тут?'; Vot takovej žizn (контаминация чеш. диал. Takovej je život c рус. Вот такая жизнь). В подобных случаях, по сути, происходит калькирование русских бессвязочных предложений, при адаптации которых, впрочем, иногда имеет место подстановка ненулевой формы глагола 'быть', ср.: Á potom fšecko jestestvenno je <...> sluňičcko, dešč i fs'o 'А потом всё естественно... солнышко, дождь - и всё’; Vot na Kuban'i <..> циot tam je

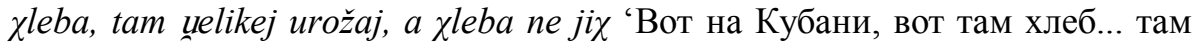
большой урожай, а хлеб не их’ и т. п.

Польские диалекты (не только переселенческие на территории Сибири), как и вообще польский язык в его устной форме, по распространенности бессвязочных предложений изначально ближе к русскому. Ввиду этого нельзя относить полностью за счет влияния РЯО, например, такие фразы носителей ВСП из текстов, собранных в [4. С. 177-184], как: Voda jiźe, kanou šerok'i 'Вода течет, канал широкий'; Uućekojmy, bo tu n'eźv'ić 'Бежим, тут медведь'; P'ens'ija mauno, že zaroboteg byц् maц̌y 'Пенсия ма-

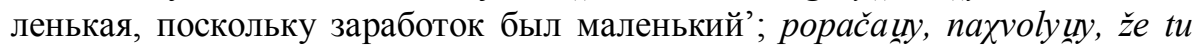
dobže 'посмотрели, расхвалили, что тут хорошо' и т. п. В ряде случаев тем не менее заметен отпечаток русского синтаксиса, характеризующегося в целом более свободным образованием чисто именных предложений, как и более широкими возможностями контекстной актуализации высказывания, cp. Mama ze s'emji Sojuf 'Мама из семьи Соя'; No po rozmov'e to <..> циuny muv'um že my is pot Krakova 'Но по речи... они говорят, что мы из-под Кракова'; Jeź n'e by uno co, jedlimy kartofle <...> Za to teros tak'i zdrovy 'Есть было нечего, ели мы картошку... Зато сейчас (я) такой здоровый’.

Еще шире представлены бессвязочные предложения в ЗСП. В этом плане примечателен проведенный в ходе нашей экспедиции 2013 г. эксперимент. Жительница Знаменки 1956 г. р. на заданный по-польски вопрос, старый ли ее дом (Czy ten dom jest stary?), отвечала чисто именными фразами N'e, on n'e mocno stari <..> vot z d'ev'an'ostovo goda, to ón jesce n'e stari, ón f tej ulici samij novi 'Нет, он не очень старый, с 90-го года, так что еще не старый, он на этой улице самый новый' и точно так же сообщила о себе: to ja na puuvove možna požešić <...> Polacka 'я наполовину, можно ска- 
зать, полька'. Когда же ее попросили перевести на родной говор фразу Czy ty jesteś Polakiem? 'Ты поляк?', она интерпретировала завершение формы 2-го л. ед. ч. глагола-связки jesteś по-своему и предложила перевод Ti tés Polak? ‘Ты тоже поляк?', который затем уточнила, на сей раз употребив унифицированную диалектную форму глагола 'быть' без лично-числового

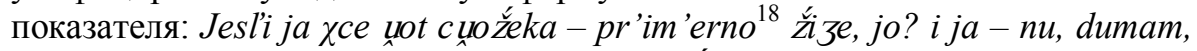
co u্রon tès n'e rusk' $i<\ldots>$ ja u n'ego spitam śe: Ti tès jest Polak? 'Вот если я хочу человека - например, вижу, да? и думаю, что он тоже не русский, я у него спрошу: Ты тоже (букв. есть) поляк?' Возможный ответ на такой вопрос, по ее словам, звучал бы так: Jo, ja jest Polak. <...> A u্রot „,mi” uźe b'ez ,jest” - il'i, da-da: Mi jest Polak'i. ‘Да, я (букв. ecmь) поляк. А вот «мы» уже без «есть» - или, да-да: Мы (букв. есть) поляки'. Аналогично: Vi jest Polak'i 'Вы поляки', но Ón'i su Polak'i 'Они поляки'. Далее собеседница одобрила составленные интервьюерами предложения Ja jest $v$ domu ' $Я$ (букв. ecmь) дома' и Ci ti tes jest $v$ domu? 'Ты тоже (букв. ecmb) дома?', но сформулированный по-русски вопрос «Где ты?» перевела так: Ti gźe tera? 'Ты где сейчас?', т.е. без глагола-связки («личный» характер которого проявляется практически только в форме 3-го л. мн. ч. $s u^{19}$ ), зато с дополнительной лексической сигнализацией плана настоящего. При явной искусственности части предложений со связкой, сконструированных в ходе экс-

${ }^{18}$ Попутно отметим, что анализируемым польским и чешским идиомам присущи также часто совпадающие специфически сибирские, воспринятые из окружающих русских диалектов «дискурсивные слова» (помимо общих для них, например, с чешскими говорами на Северном Кавказе, таких как вот, ну, в общем и др., на которые было указано в работе [23. С. 43]). Это, в частности, слова примерно в значении 'например' (и в ЗСЧ: fčera pr'im'erno sem se koukkala do sklepa 'вчера, например, я заглядывала в подвал'), вроде как средство передачи информации с чужих слов (в ВСП rustelka zakryvajum, no žeby duša śe n'e pšeglunduvauna vroźe 'зеркала закрывают, чтобы душа как бы не выглядывала' [4. С. 181], в ЗСП tam tlo šterý kłasy, a tutaj <...> vrod'e pš́jjexali, co

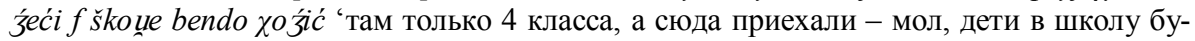
дут ходить' [3. С. 175]), частица $\partial a$ перед присоединительным союзом (в ЗСП to тuźi, ja da i tes pomagaú 'он говорит, (что) и я тоже помогала' [Там же. С. 192], в ЗСЧ d'evčata $d a$ ifs'o 'девушки, да и всё'). Из иных особенностей организации текста обращают на себя внимание частые во всех изучаемых идиомах повторы, однотипные наблюдаемым в высказываниях носителей русских говоров Сибири; например, в ВСП n'e mogli my pšeskocyź bes tyn kanounu, n'e mogli pšeskocyć 'не могли мы перепрыгнуть через этот канал, не могли перепрыгнуть' [4. С. 178]; в ЗСП roźice tutaj še roźiliti, tutaj tutaj š́e roźili 'родители наши тут родились, тут родились' [3. С. 219], в ЗСЧ n'ic sme nestonali, n'ic sme nestonali 'мы совсем не болели, совсем не болели'; ср. рус. картошка ни-ражалася вот/как вот засушыт засушыл/ вот [17. С. 84].

${ }^{19}$ Форма 1-го л. ед. ч. с особым личным показателем jestem/jezdem была зафиксирована Ступинским лишь трижды в речи единственного информанта, cp. jestem Polak po "ojcu, క́adek muj unun zavźénty Polak 'я поляк по отцу, а дед мой - он ярый поляк' [3. C. 245] с примечательным отсутствием глагола-связки во второй части высказывания. Помимо этого в молитве «Отче наш» находим форму 2-го л. ед. ч. с показателем -ś, присоединенным к местоимению: " ojce nas, kturyś jest na n'ebže 'отче наш, иже еси на небе' [Там же. С. 205]. 
перимента как информанткой, так и интервьюерами, показательны ее сомнения при выборе между ними и чисто именными предложениями, которые, по-видимому, отражают реальный колеблющийся узус в ЗСП; ср. хотя бы высказывания той же носительницы ЗСП ја na p'ens'ii jus tera и старшей по возрасту информантки (1924 г. р.) ja jus jest na p"ens’ii $i$ క̆at na $p$ "ens ' $i i$ 'я уже (букв. есть) на пенсии, и дед на пенсии' [3. С. 247].

Вместе с тем также и в польских говорах Сибири наблюдается тенденция к подстановке в некоторые предложения, в русском языке бессвязочные, форм глагола 'быть' или восходящих к ним показателей. Ср. в ВСП: Tak cyśśutko, tak fs'o por'adek jes, $f_{s}$ 'o akuratno 'Так чистенько, такой порядок (букв. есть) во всем, всё аккуратно'; Jo staro tako baba, tylem lot sama 'Я такая старая баба, столько (букв. я есть) лет одна' и Jo takom staro, fšyskom porob'iú 'Я такая (букв. есть) старая, а всё сделала'; в ЗСП: tak'e mokre přjiźem do domu... jeke tam n'el'i jeke obutk'i... peuno vody jest 'вот такие мокрые придем домой, какая там у нас была обувка - полно воды (букв. есть)'. В записях Ступинского связка јеs(t) встретилась, кроме прочего, в смешанной русско-польской и калькированной фразах: $v$ domu modlitvy <...> spševali luźe kot'oryje jus jest f tak'om v'ozrośće ot p š́ene ̌̌́e š́nt $i$ starše lat 'в молитвенном доме пели люди, которые уже (букв. есть) в таком возрасте, от 50 лет и старше'; třy lata jes, jek on pomer '3 года (букв. есть) как он умер' [Там же. С. 237, 176].

\section{Общие выводы}

Суммируя изложенное выше, можно заключить, что в синтаксисе описываемых островных западнославянских (чешского и польских) говоров в Сибири происходили и происходят во многом параллельные процессы, специфика которых состоит в непрерывном «осциллировании» между сохранением исходных диалектных систем, с одной стороны, и восприятием как частных, так и достаточно значительных фрагментов системы РЯО в его региональных разновидностях - с другой. Из РЯО неравномерно различными говорами усваивались:

1) инфинитивные конструкции ряда типов, в большей степени в ЗСЧ, тогда как для ЗСП и ВСП многие такие конструкции являлись исконными;

2) обобщенно-личные предложения с глаголом в форме 2-го л. ед. ч. одинаково во всех говорах, при сохранении достаточной устойчивости исконных для них синонимичных возвратных конструкций;

3) конструкции со страдательным причастием, особенно в полной форме без глагола-связки, распространившиеся главным образом в польских идиомах под влиянием диалектных русских конструкций, известных говорам Сибири;

4) посессивные и другие конструкции esse-типа (вместо habere-типа) повсеместно, при исконности esse-типа в случае обозначения возраста в чешском идиоме; 
5) некопулятивные предложения, в меньшей степени в ЗСЧ, в большей - в польских идиомах, где, впрочем, эти структуры часто можно считать исконными, при отмечаемых во всех говорах обратных случаях подстановки глагола в калькируемые русские предложения без связки.

За многообразием этих явлений просматривается дифференцированно действующая по говорам тенденция к известному ослаблению «глагольности» и личного характера предложения и, соответственно, к усилению в нем под влиянием РЯО именного начала и деагентивности ${ }^{20}$. Разумеется, то и другое проявляется не прямолинейно и не обязательно совпадает, как это имеет место в относящихся к плану настоящего предложениях с предикативом nado/nada в ЗСЧ или в усвоенной из русских говоров Сибири конструкции u nas fćuךk opłacone, vele Zurka n'e śecune в ЗСП и ВСП. Распространившиеся во всех исследуемых идиомах под влиянием РЯО предложения с формой 2-го л. ед. ч. глагола кажутся вполне «личными» на фоне предложений с возвратной формой глагола польского или чешского типа, но в действительности их деагентивность выше, поскольку они не «агентивизируются» даже при внедрении местоимения 'ты', как в примере ty k'edy unum'iroš из ВСП (такие конструкции с 'ты', когда говорящий не подразумевает собеседника, являются псевдоагентивными и «мнимодвусоставными»). Процесс деагентивизации вследствие спонтанного изменения стратегии построения высказывания говорящим-билингвом, выбирающим в итоге русскую модель, можно нередко наблюдать прямо в потоке речи. Так, фразу ’ o_n'au dva sini u n'ego bili носитель ЗСП начал, используя агентивную конструкцию с глаголом 'иметь', а в конце преобразовал ее в деагентивную русского типа $у$ него были (что облегчила возможная омонимия форм им. и вин. п. мн. ч. также одушевленных существительных в ЗСП).

Фиксируемый в речи информантов постоянный переход от «своих» (исконно чешских или польских) синтаксических конструкций к усвоенным русским и наоборот дает основания говорить о реализующемся во всех таких высказываниях «смешанном способе построения дискурса» [23. С. 143]. Проиллюстрирую это выдержками из записанного в мае 2017 г. интервью с единственной носительницей «кресового» польского говора с. Белосток Томской обл. Марией Маркиш. Говор этого села с изначально значительным белорусским элементом (так, даже в семье Маркиш мать была полька, а отец - белорус) являлся уже в период его формирования более «смешанным», нежели другие западнославянские переселенческие говоры Сибири. В процессе дальнейшего островного бытования в русском языковом окружении такой его характер неизбежно должен был усилиться, что и демонстрирует на синтаксическом уровне идиолект названной информантки. Интервью с ней содержит примеры едва ли не всех рассмот-

${ }^{20}$ Под деагентивностью вслед за представителями практически общепринятой в современной чешской лингвистике концепции понимается устранение персонального семантического субъекта (лица) из позиции подлежащего. 
ренных выше явлений (соответствующие места в оригинале и в русском переводе выделены курсивом): Это именные предложения без глаголасвязки, посессивная конструкция с глаголом 'быть' и выражением обладателя формой род. п. с предлогом $u$ (глагол 'иметь' в данном идиолекте отмечен только в форме с отрицанием $n$ ' $i$ ma 'нет', входящей в парадигму глагола 'быть', а не 'иметь'), конструкция с модальным предикативом $n a d a$, инфинитивные конструкции, из которых одна чисто русская (или восточнославянская), а вторая - тождественная русской исконно польская, и неопределенно-личные предложения с глаголом в 3-м л. мн. ч. (в другой записи М. Маркиш встретилось и обобщенно-личное предложение jag

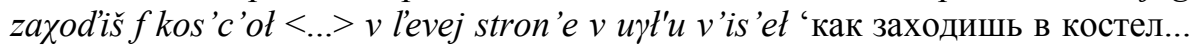
слева в углу висел'); по-видимому, наблюдается также контаминация личной и возвратной безличной конструкций, каким в общепольском соответствовали бы (ja) rozmawiałam 'я разговаривала' и rozmawiato się 'разговаривали'. Привожу в заключение этот фрагмент.

[Czy Pani mówi po polsku?]

Ot śadajće vod ze mno i ja bede vam po pol'sku zadavać vaprosy, uot tak'e. $V y$ sam'i_iskont? Sjak'i gub'ern'ii? Vy iz Maskv'y? <...> Da, ot esli pšyjeźe jaka dyfčyna po pol'sku, ja jej bede vaprosy davać: jak'if Pol'š-sk'e jenzyk, jak'i tutaj jenzyk, jak my muv'im- < ...> My k'edy kos'c'oł stojał, to my $\chi$ od'il'i... pokon'_do nas n'e pš́ijež́žali ks'onzy, to my po pol'sku fs'o vr'em'a modl'il'i s'e, a teraz nač́eli do nas pšyjižžeć po rusku juš... My juš́ i v'id'et' n'e v'idim, žep pśećitać po kš́onš́k'e.

[A czy nie zapisywał u was ktoś modlitw?] A $u$ nas jedna jest $<\ldots>$ uona po pol'sku čyta $<\ldots>$ a my kak sam'i $\chi$ ud'il'i tak my po pol'sku i nam n'e nada bylo zap 'isuvac', my po pol'sku znamy, modlili s'e... a teras ona n'i

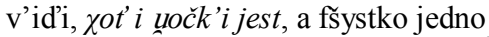
k'epsko v'iźji < ..> unot ona po pol'sku ćita <...> ja juž dużo i zapomn'auna s'e po pol'sku, temu co n'i ma s k'im s'e rozmav'ac'... jag byli ješč́e, tək rozmav'ałas', a teras n'i ma s k'im

[A w domu Pani z kim rozmawiała?] A z mamo... U n'az była mama s Pol'šy, jo pšyv'ezli s'ud'a - tšy rok'i było mam'e, to my $\mathrm{v}$ domu z mamo po pol'sku gadali. <...> Uot $u$ mojego źatka byto šez 'd' bratuf, i fs'e žyl'i tut $<$...> uot $u$ źatka mojego jedenaśće źećuv byto, fs'e žyvy byli... opš́em dužo było Pol'akuf.
[Вы говорите по-польски?!]

Вот садитесь со мной, и я буду вам попольски задавать вопросы, вот такие. Вы сами откуда? Из какой губернии? Вы из Москвы? $<$...> Да, вот если приедет какая девушка (поговорить) по-польски, я буду задавать ей вопросы: какой в Польше язык, какой тут язык, как мы говорим. <...> Мы, когда костел стоял, ходили (туда)... пока к нам не приезжали ксензды, мы по-польски все время молились, а сейчас стали к нам приезжать - уже по-русски... Мы уже и видеть не видим, чтобы прочитать по книжке.

[А молитвы у вас не записывали?]

А есть у нас одна <...> она по-польски читает $<$...> а мы, когда сами ходили, то по-польски, нам не надо было записывать, мы по-польски знаем, молились... а сейчас она не видит, хоть и очки есть, а все равно плохо видит $<\ldots>$ вот она по-польски читает <..> я уже многое и забылась (sic!) попольски, потому что разговаривать не с кем... пока еще были, так разговаривала (букв. разговаривалась), а сейчас не с кем.

[А дома вы с кем разговаривали?] А с мамой... У нас мама была из Польши, ее привезли сюда - три года было маме, вот мы дома с мамой разговаривали попольски. Вот у моего деда было шестеро братьев, и все жили тут...<..> вот у деда моего 11 детей было, и все выжили... в общем, много было поляков. 


\section{Литература}

1. Ananiewa N. Zróżnicowanie pokoleniowe polskich gwar kresowych (wybrane zagadnienia) // Gwary dziś 3. Wewnętrzne zróżnicowanie języka wsi. Poznań, 2006. S. 96-97.

2. Ананьева Н.E. Типология польских говоров Сибири и результаты их контактов с русским идиомом // Славянское языкознание. XV Международный съезд славистов, Минск, 2013 г. Доклады российской делегации. М., 2013. С. 467-478.

3. Stupiński E. Polszczyzna okolic Krasnojarska. Rozprawa doktorska napisana w Katedrze Dialektologii Polskiej UŁ. Łódź, 2009. 246 s.

4. Mitrenga-Ulitina S. Język polski mieszkańców wsi Wierszyna na Syberii. Lublin, 2015.

5. Пасько Д. Польский островной диалект жителей дер. Вершина в Сибири // Русско-польские языковые, литературные и культурные контакты. М., 2011. С. 72-80.

6. Umińska A. Gwara wsi Wierszyna (Syberia Wschodnia). Pozostałości języka polskiego w płaszczyźnie fonetycznej i leksykalnej // Słowiańskie wyspy językowe i kulturowe. Toruń, 2013. S. 27-42.

7. Gtuszkowski M. Socio-cultural and Language Changes in a „Cultural Island”: Vershina-A Polish Village in Siberia // Eastern European Countryside. 2014. Vol. 20, Iss. 1. P. 167-188.

8. Ананьева Н.Е. Морфология глагола в польском говоре деревни Вершина Боханского района Иркутской области // Исследования по славянской диалектологии. М., 2013. Вып. 16. С. 203-210.

9. Ананьева Н.Е. Островной польский диалект // Актуальные этноязыковые и этнокультурные проблемы современности. М., 2015. Кн. 2. С. 9-18.

10. Егоров И.М. Фонетические особенности польского переселенческого говора в Республике Хакасия и в Красноярском крае РФ // Полевые исследования студентов РГГУ VIII. М., 2013. С. 98-109.

11. Jegorow I. Zur Sprachsituation und ethnischen Identität in zwei von den historischen ostpreußischen Masuren besiedelten Dörfern in Sibirien // Junge Slavistik im Dialog VI. Beiträge zur XI. Internationalen Slavistischen Konferenz. Hamburg, 2017. S. 97-105.

12. Skorwid S. Składniki tożsamości narodowej potomków polskich przesiedleńców z Mazur w Republice Chakasji i Krasnojarskim kraju FR // Acta Neophilologica XVIII/1. Olsztyn, 2016. S. 125-134.

13. Скорвид С.С. Говор чехов Среднего Прииртышья: генезис и своеобразие // Вестник Омского университета. 2013. № 3. С. 129-135.

14. Скорвид С.С. Чешские переселенческие говоры на Северном Кавказе и в Западной Сибири // Славяноведение. 2014. № 1. С. 44-58.

15. Skorvid S. Czech immigrant dialects in the Northern Caucasus and Western Siberia // International Journal of the Sociology of Language. 2016. Iss. 238. P. 127-143.

16. Hakenová B. Jazyk české menšiny ve vesnici Repinka na Sibiři. Magisterská diplomová práce. Filozofická fakulta Univerzity Karlovy v Praze, Ústav českého jazyka a teorie komunikace. Praha, 2015. $127 \mathrm{~s}$.

17. Харламова М.A. Константы народной речемысли и их лексикографическая интерпретация. Омск, 2014. С. 52-65.

18. Скорвид С.С. К типологии инославянских переселенческих говоров в России // Slověne $=$ Словъне. International Journal of Slavic Studies. 2017. Vol. 6, № 1 .

19. Nitsch K. (red.) Północno-polskie teksty gwarowe od Kaszub po Mazury. Kraków, 1955.

20. Skorwid S. Gramatyczne germanizmy rdzennych dialektów zachodniosłowiańskich w gwarach przesiedleńczych na terenie Rosji // Gwary dziś 7. Rocznik poświęcony dialektologii słowiańskiej. Poznań, 2015. S. 177-190.

21. Urbańczyk S. Zarys dialektologii polskiej. Warszawa, 1984. Wyd. 7.

22. Скорвид С.С., Поляков Д.К. О проницаемости грамматической системы в ситуации межъязыковой интерференции в говоре потомков чешских переселенцев на Северном Кавказе // Исследования по славянской диалектологии. М., 2013. Вып. 16. С. 305-337. 
23. Поляков Д.К. Интерференционные процессы и гибридизация в переселенческих говорах // Гибридные формы в славянских культурах. М., 2014. С. 132-147.

24. Колесов В.В. (ред.) Русская диалектология. М., 1990.

\section{ON THE PARALLEL SYNTACTIC PROCESSES IN WEST SLAVIC INSULAR DI- ALECTS IN SIBERIA}

Vestnik Tomskogo gosudarstvennogo universiteta. Filologiya - Tomsk State University Journal of Philology. 2018. 53. 75-97. DOI: 10.17223/19986645/53/6

Sergej S. Skorvid, Russian State University for the Humanities (Moscow, Russian Federation). E-mail: slavcenteur@gmail.com

Keywords: Czech \& Polish dialects, insular immigrant varieties, Western and Eastern Siberia, language contact, verbal and nominal syntactic constructions, deagentivity.

The paper deals with similar syntactic features seen in one Czech and two Polish immigrant dialects, which are still spoken in Siberia. The Czech dialect is used in three villages in the Middle Irtysh area of Omsk Oblast, and the Polish ones in two villages in Krasnoyarsk Krai and in the Republic of Khakassia, and in one village in Irkutsk Oblast. Besides that, an idiolect of the last user of the Polish patois formerly spoken in one village located in Tomsk Oblast is taken into consideration. Despite the fact that each of those varieties has already been described in dialectological works by Russian and Polish (less by Czech) researchers, their resemblance at the syntactic level which occurred due to the contacts with common Russian, as well as with its regional forms has not become an object of attention until now. The author analyses such features as:

1) impersonal constructions, especially with infinitives and modal predicates like nado/nužno 'it is needed', borrowed from Russian;

2) other deagentive constructions, both formally personal and impersonal, i.a. reflexive and participle constructions of different types (among the latter those ones which were probably influenced by Russian dialects spoken in Siberia, like Polish rozony ja or Czech narozená sem 'I was born' etc.);

3) possessive constructions of Russian 'to be' type, also without copula in the present tense, widespread in all the immigrant dialects under examination, along with original 'to

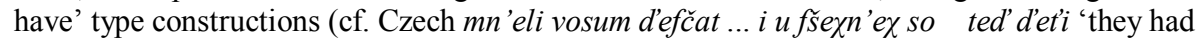
eight girls, and all of them have their own children now');

4) other non-copulative sentences coexisting with copulative (verbal) phrases used even if calquing the Russian purely nominal pattern (cf. Polish ja na p'ens'ii jus tera / ja jus jest na $p$ 'ens ' $i i$ 'I am already retired now').

It is stated that the speakers of the examined dialects permanently oscillate in their discourse between originally West Slavic sentence structures and their correspondences in Russian. Such a situation leads to the origin of a mixed code which is fully understandable only within the insular community where it is used. As with the expansion of modern urban civilization all of the dialects in question have not been naturally transmitted across generations and at the present time they are gradually disappearing, it is no doubt that very soon we will be able to trace in each case at most single marks of this code in the totally Russian speech of the descendants of former immigrants.

\section{References}

1. Ananiewa, N. (2006) Zróżnicowanie pokoleniowe polskich gwar kresowych (wybrane zagadnienia) [Generational differences in Polish borderland dialects (selected questions)]. In: Sierociuk, J. (ed.) Gwary dziś 3. Wewnętrzne zróżnicowanie języka wsi [Dialects today 3. Internal differentiation of rural language]. Poznan: Wydawnictwo Poznańskiego Towarzystwa Przyjaciół Nauk.

2. Ananieva, N.E. (2013) Tipologiya pol'skikh govorov Sibiri i rezul'taty ikh kontaktov s russkim idiomom [Typology of Polish dialects in Siberia and the results of their contacts with 
Russian idiom]. In: Moldovan, A.M. \& Tolstaya, S.M. (eds) Slavyanskoye yazykoznaniye. XV Mezhdunarodnyi syezd slavistov. Minsk, $2013 \mathrm{~g}$. Doklady rossiyskoy delegatsii [Slavic linguistics. XV. International Congress of Slavists. Minsk 2013. Contributions of Russian Delegation]. Moscow: Indrik.

3. Stupiński, E. (2009) Polszczyzna okolic Krasnojarska. Rozprawa doktorska napisana w Katedrze Dialektologii Polskiej UŁ [Polish language in Krasnoyarsk vicinity. Dissertation written at the Department of Polish Dialectology of the UL]. Lodz. (manuscript).

4. Mitrenga-Ulitina, S. (2015) Język polski mieszkańców wsi Wierszyna na Syberii [Polish language of the inhabitants of the village Vershina in Siberia]. Lublin: Wydawnictwo Uniwersytetu Marii Curie-Skłodowskiej.

5. Paśko, D. (2011) Polskiy ostrovnoy dialekt zhitelei der. Vershina v Sibiri [Polish insular dialect of the inhabitants of the village Vershina in Siberia]. In: Grzybowski, S., Khoryev, V.A. \& Wołos, M. (eds) Russko-polskiye yazikovye, literaturnye $i$ kulturnye kontakty [Russian-Polish language, literary and cultural contacts]. Moscow: Kvadriga.

6. Umińska, A. (2013). Gwara wsi Wierszyna (Syberia Wschodnia). Pozostałości języka polskiego w płaszczyźnie fonetycznej i leksykalnej [The dialect of the village Vershina (Eastern Siberia). Polish phonetic and lexical features]. In: Nowicka, E. \& Głuszkowski, M. (eds.) Stowiańskie wyspy językowe i kulturowe [Slavonic language and cultural islands]. Torun: Eikon.

7. Głuszkowski, M. (2014) Socio-cultural and Language Changes in a "Cultural Island": Vershina - A Polish Village in Siberia. Eastern European Countryside. 20/1. pp. 167-188.

8. Ananieva, N.E. (2013). Morfologiya glagola v pol'skom govore derevni Vershina Bokhanskogo rayona Irkutskoy oblasti [The morphology of the verb in the Polish dialect in the village Vershina in Bokhansky District of Irkutsk Oblast]. In: Kalnyn, L.E. (ed.) Issledovaniya po slavyanskoy dialektologii [Studies in Slavic Dialectology]. 16. Moscow: Institut slavyanovedeniya RAN.

9. Ananieva, N.E. (2015) Ostrovnoy polskiy dialekt [An insular Polish dialect]. In: Neshchimenko, G. P. (ed.) Aktualnye etnoyazykovye i etnokulturnye problemy sovremennosti [Topical ethnolinguistic \& ethnocultural problems of the present time]. Book 2. Moscow: Yazyki slavyanskikh kultur.

10. Egorov, I.M. (2013) Foneticheskie osobenosti pol'skogo pereselencheskogo govora v Respublike Khakasiya i v Krasnoyarskom kraye RF [Phonetic features of the Polish immigrant dialect in the Republic of Khakassia and in Krasnoyarsk Krai of the RF]. In: Pivovar, E.I. Polevye issledovaniya studentov $R G G U$ [Field research of students of the RSUH]. VIII. Moscow: RSUH.

11. Jegorow, I. (2017) Zur Sprachsituation und ethnischen Identität in zwei von den historischen ostpreußischen Masuren besiedelten Dörfern in Sibirien [On the linguistic situation and ethnic identity in two Siberian villages inhabited by historically East Prussian Masurs]. In: Weigl, A. et al. (eds) Junge Slavistik im Dialog VI. Beiträge zur XI. Internationalen Slavistischen Konferenz [Young Slavistics in Dialogue VI. Contributions to the XI International Conference in Slavistics]. Hamburg: Verlag Dr. Kovač.

12. Skorwid, S. (2016) Składniki tożsamości narodowej potomków polskich przesiedleńców z Mazur w Republice Chakasji i Krasnojarskim kraju FR [The components of national identity of the descendants of the Polish immigrants from Masuria in the Republic of Khakassia and Krasnoyarsk Krai of the RF]. Acta Neophilologica. XVIII/1.

13. Skorvid, S.S. (2013) Govor chekhov Srednego Priirtysh'ya: genezis i svoeobrazie [The Czech dialect in the Middle Irtysh area of Russia: origin and specificity]. Vestnik Omskogo universiteta - Herald of Omsk University. 3 (69). pp. 129-135.

14. Skorvid, S.S. (2014) Cheshskiye pereselencheskie govory na Severnom Kavkaze i v Zapadnoy Sibiri [Czech migrant dialects in the Northern Caucasus and in Western Siberia]. Slavyanovedeniye - Slavic Studies. 1. pp. 44-58.

15. Skorvid, S. (2016) Czech immigrant dialects in the Northern Caucasus and Western Siberia. International Journal of the Sociology of Language. 238. pp. 127-143. 
16. Hakenová, B. (2015) Jazyk české menšiny ve vesnici Repinka na Sibiři [The language of a Czech minority in Repinka in Siberia]. Diploma paper. Charles University in Prague, Faculty of Arts, The Institute of Czech Language and Theory of Communication. Prague. (manuscript).

17. Kharlamova, M.A. (2014) Konstanty narodnoy rechemysli i ikh leksikograficheskaya interpretatsiya [The constants of the folk "speech-thought" and their lexicographical interpretation]. Omsk: Omsk State University.

18. Skorvid, S.S. (2017) K tipologii inoslavyanskikh pereselencheskich govorov v Rossii [On the typology of the alien Slavic immigrant dialects in Russia]. Slověne. International Journal of Slavic Studies. 6/1. (in print).

19. Nitsch, K. (1955) Pótnocno-polskie teksty gwarowe od Kaszub po Mazury [Northern Polish dialectal texts from Cassubia up to Masuria]. Krakow: Towarzystwo miłośników języka polskiego.

20. Skorwid, S. (2015) Gramatyczne germanizmy rdzennych dialektów zachodniosłowiańskich w gwarach przesiedleńczych na terenie Rosji [Grammatical Germanisms of the ascendant dialects in West Slavic immigrant patois in Russia]. Gwary dziś. 7.

21. Urbańczyk, S. (1984) Zarys dialektologii polskiej [An Outline of Polish Dialectology]. Warsaw: PWN.

22. Skorvid, S.S. \& Polyakov, D.K. (2013) O pronitsayemosti grammaticheskoy sistemy v situatsii mezhyazykovoy interferentsii $\mathrm{v}$ govore potomkov cheshskich pereselentsev na Severnom Kavkaze [On the penetrability of the grammatical system under circumstances of interlingual interference in the dialect of descendants of Czech settlers in the Northern Caucasus]. In: Kalnyn, L. E. (ed.) Issledovaniya po slavyanskoy dialektologii [Studies in Slavic Dialectology]. 16. Moscow: Institut slavyanovedeniya RAN.

23. Polyakov, D.K. (2014) Interferentsionnye protsessy i gibridizatsiya v pereselencheskikh govorakh [Inferential processes and hybridization in immigrant dialects]. In: Zlydneva, N. (ed.) Gibridnye formy $v$ slavyanskikh kulturakh [Hybrid forms in Slavic cultures]. Moscow: Polimedia.

24. Kolesov, V.V. (ed.) (1990) Russkaya dialektologiya [Russian dialectology]. Moscow: Vysshaya shkola. 